\title{
A Small-States Perspective on the European Citizens' Initiative
}

\author{
Maximilian Conrad, Ph. D., Assistant Professor, University of Iceland
}

\begin{abstract}
The introduction of the European Citizens' Initiative (ECI) in the Lisbon Treaty has given the European Union (EU) its strongest element of transnational participatory democracy to date. One million EU citizens from at least seven different member states can now request legislative proposals from the European Commission. This article discusses the ECI from a small-states perspective, assessing its impact on the role of small-state citizens in the union. The theoretical argument draws both on the international relations literature on small states and on James Bohman's work on transnational democracy, suggesting that the ECI is a particularly fruitful tool that gives EU citizens an institutional incentive for initiating deliberation on perceived injustices. The empirical argument presents the findings of a quantitative analysis of the organizers of the first sixteen initiatives, suggesting that the ECI is indeed a tool used by citizens from the union's smaller states. However, the analysis also shows that state size can and should be conceptualized not merely in terms of traditional indicators such as most importantly population size, but also in terms of constructivist notions of perceptual size.
\end{abstract}

Keywords: European Union (EU); European Citizens' Initiative (ECI); transnational democracy; participatory democracy; small states. 


\section{Introduction}

\subsection{Background}

The Lisbon 'Treaty introduced the European Citizens' Initiative (ECI) as the world's first transnational citizens' agenda initiative, thereby providing EU citizens with the strongest instrument of participatory democracy in the European Union to date. ${ }^{1}$ Since the ECI became legislative reality in April 2012, EU citizens have therefore been able to draft ideas for legislative proposals and gather signatures in their support. Provided that certain formal requirements are met, initiatives supported by the signatures of at least one million EU citizens can force the European Commission to submit a legislative proposal to the European Parliament and the Council of Ministers. ${ }^{2}$ At the time of writing, the first initiatives that were launched in the spring of 2012 have just finished their respective signature collection processes. ${ }^{3}$ Three initiatives, namely Right $2 W$ ater, One of us and Stop Vivisection, ${ }^{4}$ managed to pass the required mark of one million signatures. ${ }^{5}$

From the outset, the ECI has been hailed as an important democratic innovation with at least some potential to bridge the long-bemoaned gap between the EU institutions and the EU's citizens that is often captured under the rubric of the democratic deficit (e.g. Maurer \& Vogel 2009; Conrad 2011; Quittkat 2012; Bouza García 2012; Smith 2012). So far, the potential of the ECI has however not been explored from a smallstates perspective, investigating how it could affect the role of small states and their citizens in the EU's legislative process. Much attention has in recent years been paid to the question of the power potential of small(er) states in the EU (e.g. Jónsdóttir 2013; Broman 2008). This question has also been among the most prominent ones in Icelandic political debate on the prospect of EU membership. ${ }^{6}$ However, no similar interest has so far been directed towards the ECI.

To some extent, this is understandable, considering that the ECI will not directly affect the position of smaller states in the EU's institutions. In a sense, the question may therefore come across as somewhat misguided, considering that after all, the fundamental ambition behind the ECI was to create a new element of participatory democracy to complement the already existing elements of representative democracy (cf. Kaufmann 2012: 229-233; Smith 2012: 278-280). ${ }^{7}$ Therefore, the ECI strengthens the role of European citizens as such, not of states or their governments, as has already been pointed out in response to a similar question asked on Evrópuvefurinn (Conrad 2012), the Icelandic Parliament's and the University of Iceland's joint information website on the European Union. In this sense, the ECI's potential contribution to alleviating the democratic deficit lies primarily in offering institutional incentives for the activation of the transnational dimension of EU citizenship. EU citizenship was created in the Maastricht Treaty on European Union in 1993 as a set of political rights that individuals enjoy as nationals of their respective member states, yet regardless of the member state that they reside in (e.g. Bache et al. 2011: 164; Smismans 2013: 344f.). ${ }^{8}$ The same applies to the organization of European citizens' initiatives. The requirement that ECI organizers have to reside in at least seven different member states underlines the ECI's role in fostering transnational democracy as well as a sense of identification with the European polity (Conrad 2011). 


\section{STJÓRNMÁL \& \\ STJÓRNSÝSLA}

This also suggests that the ECI can serve as an institutional tool allowing citizens from the union's small(er) states to make their voices heard in the EU's legislative process, provided that they manage to identify likeminded co-organizers in other member states.

The ECI furthermore illustrates key points raised in James Bohman's account of transnational democracy as a model for democracy beyond the nation state (Bohman 2005, 2007a, 2007b). Because democracy is rooted as deeply as it is in the nation state, Bohman proposes "decentering" democracy in the sense of not aiming for the construction of a singular European demos that can serve as the basis for popular sovereignty at the European level. ${ }^{9}$ Instead, non-domination should be taken as the normative ideal of transnational democracy and should be ensured through the development of institutional means that allow citizens to raise awareness for and initiate deliberation on perceived injustices. For sure, this does not primarily refer to the initiation of deliberation on the interests of specific communities, whether national, subnational or otherwise. However, it clearly has relevance from a small-states perspective, as it allows small-state citizens to play the same role in organizing citizens' initiatives as their counterparts in the union's larger states. Therefore, there is clearly an interest not only in analyzing the kind of issues that are addressed by European citizens' initiatives, but more importantly the role that citizens from the union's smaller and smallest states play in the initiation and organization of European citizens' initiatives.

\subsection{Research questions}

This article therefore addresses the ECI's democratic potential from a small-states perspective, that is: it looks at the potential that the ECI has for citizens of the union's small(er) states, not for those states and/or their governments as such. This analysis includes both theoretical and empirical aspects. The theoretical argument is based on Bohman's work on transnational democracy (Bohman 2005, 2007a, 2007b) and argues that the ECI is an institutional innovation that provides citizens with the kind of opportunity to initiate deliberation that Bohman views as necessary to ensure non-domination (ibid.; cf. Conrad 2011). The empirical analysis, on the other hand, looks at the extent to which citizens from the union's smaller and smallest states take advantage of this opportunity, regardless of what compels them to do so. It should be made clear already at this point that the article has no explanatory ambition and therefore cannot claim to establish any causal links between state size and the organization of European citizens' initiatives. Based on information that is publicly available via the European Commission's ECI website as well as via the different initiatives' own websites, the article presents an analysis of the role that citizens from small(er) states play in the organization of the first sixteen initiatives that were launched between May 2012 and July 2012. ${ }^{10}$

The main empirical aim of the article is thus to map who the organizers of the first sixteen initiatives are and to discuss its findings from a small-states perspective. To this end, the article draws on two different conceptualizations of state size, namely the more traditional measure of population size on the one hand, and on the other hand the notion of perceptual size as developed by Thorhallsson (2006). 


\section{STJÓRNSÝSLA}

\subsection{Organization of the article}

The following section 2 covers some of the organizational aspects of the ECI, arguing precisely that the ECI is an instrument of participatory democracy that therefore needs to be distinguished both from direct-democratic elements that are still missing at the European level, and from those elements of representative democracy that are spelled out in article 10 of the consolidated Treaty on European Union (TEU). ${ }^{11}$ Section 3 takes this argument one step further by arguing that the ECI is in fact an instrument of a highly particular form of participatory democracy, namely transnational participatory democracy. As such, it provides an opening for realizing the normative goals spelled out in Bohman's account of transnational democracy, namely to ensure non-domination in a decentered polity, that is: a polity composed of a plurality of already existing and democratically constituted (nation-state) demoi. This section also discusses the relevance of the ECI from a small-states perspective. Section 4 presents the findings of the empirical analysis, discussing the role of small-state citizens in the organization of the first sixteen initiatives in relation to two different conceptualizations of state size, namely (a) population size and (b) perceptual size.

\section{Organizational Aspects}

\subsection{Organizational Aspects I: The $\mathrm{ECl}$ as an instrument of participatory democracy}

The introduction of a form of citizens' initiative, at first in the failed Constitutional Treaty and ultimately in the Lisbon Treaty ${ }^{12}$, has to be understood in the context of the long-bemoaned democratic deficit in the EU. This deficit is certainly by no means merely an institutional deficit along the lines of weak accountability relationships (Conrad 2011). Nonetheless, the oft-cited gap between the EU institutions and the citizens certainly has an institutional component. After all, only the European Parliament (EP) is directly elected by the citizens, and even EP elections are organized on the national level, with domestic parties frequently campaigning on domestic issues (Burns 2013: 168). In addition, the European Parliament still has no formal right of legislative initiative apart from being allowed to request legislative proposals from the European Commission (Warleigh-Lack \& Drachenberg 2013: 202). And although the EP plays an increasing role in the formal election of the Commission President and the approval of the College of Commissioners (Burns 2013: 162), the EP arguably still has a long way to go before it will be more directly involved in the selection of the Commission President - possibly in the form of the transnational party groups presenting their own candidates in the run-up to the EP elections (cf. Conrad \& Steingrímsdóttir 2012). ${ }^{13}$

Consequently, the European Union is a representative democracy only in a highly indirect way, considering not least the still strong role of the European Council as an agenda-setter in the legislative process. This necessitates that the union's representativedemocratic elements (spelled out in art. 10 TEU) be complemented with elements of participatory democracy (art. $11 \mathrm{TEU}$ ). The ECI is arguably the strongest of these participatory elements. Although the right to petition the EP has existed since the introduction of EU citizenship in the Maastricht Treaty (art. 20 TFEU) over twenty years ago, a 


\section{STJÓRNMÁL \\ STJÓRNSÝSLA}

successful citizens' initiative supported by over a million citizens quite obviously carries more force than a petition. As such, the ECI has a much clearer potential to function as a bridge-builder between the citizens and the European institutions, also because at least some initiatives can be expected to follow the lead of the Right $2 \mathrm{Water}$ campaign and generate significant communicative power and channel it from the public sphere into the political system (Conrad 2013), thereby having a democratizing effect along the lines of the Habermasian understanding of deliberative democracy (Habermas 1992). Also at the level of knowledge production, the ECI is connected to hopes for the emergence of transnational discursive spheres that are similarly connected to enhancing the democratic quality of EU decision making (Knaut \& Keller 2012).

But in addition to the mentioned institutional and communicative aspects, the EU democratic deficit is also marked by significant affective deficits, i.e. the lack of a deeper sense of collective identification with the project of European integration on the part of the European citizens (e.g. Warleigh 2003: chap. 6). Communitarians tend to bemoan the absence of a European sense of normative-affective community as a challenge to the level of supranational integration that has occurred in Europe at least since the Treaty on European Union (e.g. Etzioni 2007). Yet while this "community deficit" is said to be a more profound problem for the EU than the presumed democratic deficit (which, intergovernmentalists still maintain, is itself a myth (Moravcsik 2008)), the argument in this article is instead that both are sides of the same coin: the lack of strong accountability relationships, hitherto paired with less-than-convincing participatory mechanisms, stands in the way of a self-identification of Europeans as parts of the same political community (Conrad 2013).

\subsection{Organizational Aspects II: The $\mathrm{ECl}$ as an instrument of transnational partici- patory democracy}

The ECI is highly intriguing in this regard because it provides incentives for the activation of the transnational dimension of EU citizenship (cf. Leinen 2012: 31). EU citizenship as such is nothing new, having been introduced in the Maastricht Treaty over twenty years ago and giving nationals of EU member states individual rights such as e.g. the right to vote and run for office in elections to the European Parliament as well as municipal elections in their state of residence without being a citizen of that particular state. ${ }^{14}$ The ECI adds a transnational dimension to the rights of EU citizens not only because EU citizens can use their right to organize initiatives no matter where they reside within the union, but more importantly because it requires them to find co-organizers in at least one quarter of the union's 28 member states. The organization of an ECI thus requires transnational civil society networking, in addition to which ECIs have to reach a minimum number of signatures in at least one quarter of the member states. ${ }^{15}$

Ideally, citizens from a variety of national backgrounds would come forward to identify issues of shared concern and find likeminded citizens in other member states who are willing to co-organize an initiative. In the process, this would facilitate the emergence of transnational discursive spheres in which deliberation about the justification 


\section{STJÓRNSÝSLA}

and legitimacy of their concern is initiated. If those expectations are fulfilled, the ECI could even turn out to be much more than an instrument of transnational participatory democracy. In fact, it could also be a tool that ultimately leads - via the emergence of transnational discursive spheres - to some sense of transnational deliberative democracy. The focus in this article is however not on the latter two claims. Even the transnational networking aspect is complicated by the fact that at least in a number of cases, an organizer's country of origin (and citizenship) no longer necessarily has to coincide with their country of residence. Some initiatives are consequently organized by citizens from only a very limited number of member states. In addition, although the formal organizers of a number of initiatives may represent the prescribed variety of countries, the actual work is in some cases done by much smaller groups based in one specific location. It remains to be seen to which extent these are exceptions proving the rule, and of course to assess to which extent this constitutes a challenge to the transnationally conceived ECI.

Regarding the ECI's transformative potential, a number of aspects deserve specific attention. For Bohman, transnational democracy needs to take the problem of a "hierarchy of authority" seriously. A hierarchy of authority emerges by necessity when trying to reconstitute the normative ideal of popular sovereignty in a polity composed of a multitude of already democratically constituted demoi (Bohman 2005, 2007a, 2007b). The European Union is a case in point, where the question of the relationship between existing national (and indeed subnational demoi) and an overarching (yet to be constructed) European demos remains unsettled. For Bohman, reconstituting popular sovereignty, e.g. at the European level, through the creation of a European demos is inherently problematic because it may result in a view of national (and subnational) demoi as normatively secondary. This in turn creates a potential for domination not just of smaller units at the hands of bigger ones, but also domination of minority groups and their concerns. Again, these need not be national or subnational groups within larger nation states; the normative ideal of non-domination is equally relevant in the context of e.g. LGBT rights, or the rights of cultural minorities within nation states. Therefore, Bohman calls for an understanding of democracy focusing on the achievement of non-domination instead of some vague notion of popular sovereignty. To ensure this, individuals have to be able to initiate deliberation on perceived injustices, and this deliberation has to be linked directly to the institutions of the political system.

It takes no great leap of the imagination to interpret the ECI as a participatorydemocratic instrument that provides citizens with strong opportunities to initiate deliberation on perceived injustices. As a matter of fact, the purely awareness-raising function of inadmissible initiatives (regarding issues on which the Commission does not have the authority to propose legislation) is a case in point (Bouza \& Greenwood 2013), and is further underlined e.g. by campaigns for a European-wide right to same-sex marriage. But while the ECI has a clear potential as an awareness-raising instrument for minority concerns, it should also be discussed from a perspective focusing on the concerns of smaller EU member states.

In this context, it also has to be discussed whether and to what extent it is necessary 


\section{STJÓRNMÁL \\ STJÓRNSÝSLA}

for small-state citizens to make use of the ECI, and no less whether and to what extent the ECI could be seen as a tool that can increase the role and power potential not of small states as such, but of the citizens of small states in the EU. This discussion could be seen as paralleling a similar discussion about the power potential of small-state MEPs in the European Parliament. Although the smaller member states are quite heavily overrepresented in the EP due to the principle of digressive proportionality (Dinan 2010: 238), they are nonetheless outnumbered by MEPs from the union's larger states. However, MEPs usually sign up to one of the EP's transnational party groups, have policy preferences closer to other members of their own group than to those of domestic members of other groups, and most importantly have considerably more influence as a transnational party group than they would on their own.

The impact of the role of small-state citizens in the context of the ECI can be considered as quite similar. Due to the ECI's transnational character, organizers coming from small states need to find co-organizers in other and, ideally, larger member states. As we will see below, fifteen of the member states of the EU-28 can be categorized as medium-small or small (on the basis of population size). However, reaching the required mark of one million signatures in support of any given initiative is evidently considerably easier if support is also drawn from the union's larger states. In addition, and very similar to the party-political dynamics playing out in the European Parliament, most of the issues and concerns addressed in the first sixteen citizens' initiatives analyzed here have a clear transnational character, that is: they address perceived injustices that are similarly salient across member states. ${ }^{16}$ Still, the question remains whether citizens from the union's smaller and smallest states are active in driving European citizens' initiatives, or whether they play a more passive role in co-organizing initiatives.

\section{Who organizes ECls - and why?}

\subsection{Methodological Reflections on State Size}

As the ECI has already been legislative reality for over a year and a half, this analysis can draw on the experiences of a fair amount of initiatives to analyze the role of small-state citizens as ECI organizers. In this empirical analysis, the primary interest is on how many of the first sixteen initiatives are organized by citizens from the union's smaller and smallest states. The analysis distinguishes between the organizational roles played by the respective "representatives", "substitutes" and the remaining members of an initiative's “citizens' committee”. Following the ECI Regulation ${ }^{17}$, an initiative formally needs to be organized by a "citizens' committee" consisting of seven people, including a main "representative", a "substitute", and five other members. The degree of involvement in the day-to-day organization of the initiative varies; in most cases, however, most of the work is done by a relatively limited number of individuals. This varying level of involvement is here captured by assigning a different number of points based on the specific role that an individual plays in the organization of the campaign (see below).

More relevantly, the concept of state size needs to be discussed. In the international politics literature, state size is traditionally defined by reference to variables such as pop- 


\section{STJÓRNSÝSLA}

ulation, territory, GDP, in some cases military expenditure, and so on (cf. Thorhallsson 2006). It may be worth noting that the concept of state size is relevant only to the extent that it allows us to understand the behavior of states in international politics. In this context, Thorhallsson has argued that traditional variables cannot provide a full picture of when, how and why small states matter, e.g. in the institutional environment of the European Union (ibid.; cf. Conrad \& Steingrímsdóttir 2012). For Thorhallsson, it is clear that the behavior of states also needs to take into account notions of "perceptual size", that is: how states which are small in relation to traditional variables are seen by others, but maybe more importantly how they see themselves and their ability to play a role in international politics (Thorhallsson 2006: 24f.).

Thorhallsson's reflections on the relevance of perceptual size lead this analysis to propose two different ways of looking at state size in the EU: one derived from the traditional variable of population size, one derived from the notion of perceptual size. Defining state size in relation to population size is arguably fairly straight forward. Here, the analysis draws on a distinction between five different categories of state size, based on the number of representatives that each state has in the European Parliament. Table 2 shows that the differences in size between large, medium-large and medium-sized states in the EU are considerable. The boundary is somewhat more blurry between the medium-sized and medium-small states, as e.g. Sweden could also be argued to fall into the category of medium-sized states.

Table 1. Population size as defined by representation in the European Parliament

\begin{tabular}{|l|c|c|l|}
\hline Category & Number of seats in EP & Number of states & States included \\
\hline Large & $73-99$ & 4 & GER, FRA, ITA, UK \\
\hline Medium-large & 54,51 & 2 & ESP, POL \\
\hline Medium & $33-22$ & 7 & ROM, NL, BEL, CZE, GRE, HUN, POR \\
\hline Medium-small & $20-12$ & 9 & SWE, AUT, BUL, FIN, DK, SLK, IRE, CRO, LIT \\
\hline Small & $9-6$ & 6 & LAT, SLN, CYP, EST, LUX, MAL \\
\hline
\end{tabular}

Perceptual size is obviously a concept whose aim is to understand the behavior of states in international politics. Since the aim of the present analysis is however to relate perceptual size to the activities of citizens - in this case in relation to the ECI -, emphasis has to be placed on the way citizens perceives themselves and their role in European 


\section{STJÓRNMÁL \& STJÓRNSÝSLA}

integration. Three of the questions asked in the Standard Eurobarometer are of particular relevance here, namely to what extent citizens from different member states (a) find that their "voice counts in the European Union"; (b) feel "like a citizen of the European Union"; and (c) have "knowledge of [their] rights as citizen[s] of the European Union" (Standard Eurobarometer 79).

The question regarding whether or not "my voice counts in the EU" is arguably somewhat more relevant to the analysis than the other two. However, a combination of all three questions arguably gives us a fairly good account of how citizens of the different member states perceive themselves and their influence as active citizens of the EU. In this regard, we can broadly distinguish between three different groups of member states (see table 1): states with aggregate average scores of $55 \%$ and over are ranked as perceptually large states; states with scores under $40 \%$ are ranked as small states; and states between $40 \%$ and $55 \%$ are ranked as medium-sized states.

The citizens of Luxembourg and Denmark are at the top as the only states with averages over $60 \%$, meaning that on average, more than $60 \%$ of their citizens feel like "citizens of the union", find that their "voice counts in the EU" and that they have "knowledge of their rights as EU citizens". In total, ten states fall into the category of perceptually large states, whereas the two other groups consist of nine (medium-sized) and eight (small) states, respectively. Notably, the group of perceptually small states includes those Southern European states that have been worst affected by the Eurozone debt crisis, such as Greece and Cyprus, but also Italy.

The question of whether citizens consider their voice to count in the EU can be considered to be of particular relevance to the concept of perceptual size. Denmark stands out in this regard, being the only state in the EU-28 in which an absolute majority finds that their voice matters in the EU. More than $40 \%$ find that this is the case in Croatia, Luxembourg, Belgium, Sweden and Malta. At the other end of the spectrum, only a very small percentage of the citizens of Greece (11\%) and Cyprus (9\%) find that their voice counts. Maybe more importantly, Spain and Portugal are here ranked as perceptually medium-sized states due to their relatively high average scores (41\% and 43\%, respectively). However, the Spaniards' and Portuguese perception of whether their voice counts in the EU is exceptionally low (18\% and 16\%, respectively), which is unusually low in relation to the average for states in this category $(27 \%)$. 


\section{STJÓRNSÝSLA}

Table 2. Perceptual size: Self-perceptions of citizens of the EU-28

\begin{tabular}{|c|c|c|c|c|c|}
\hline Cat. & State & $\begin{array}{l}\text { "My voice counts } \\
\text { in the EU" }\end{array}$ & $\begin{array}{c}\text { "Feeling like a citizen } \\
\text { of the union" }\end{array}$ & $\begin{array}{l}\text { "Knowledge of rights } \\
\text { as EU citizens" }\end{array}$ & Average \\
\hline \multirow{8}{*}{ 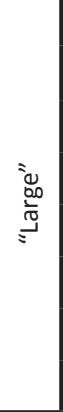 } & Luxembourg & 46 & 88 & 67 & 67 \\
\hline & Denmark & 56 & 71 & 59 & 62 \\
\hline & Malta & 45 & 81 & 51 & 59 \\
\hline & Finland & 33 & 73 & 65 & 57 \\
\hline & Germany & 36 & 73 & 61 & 56.7 \\
\hline & Belgium & 48 & 71 & 47 & 55.3 \\
\hline & Poland & 37 & 70 & 59 & 55.3 \\
\hline & Sweden & 41 & 69 & 55 & 55 \\
\hline \multirow{11}{*}{ 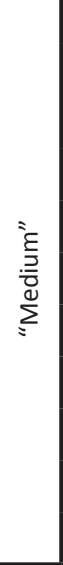 } & Slovakia & 28 & 76 & 59 & 54.3 \\
\hline & Austria & 33 & 66 & 56 & 51.7 \\
\hline & Netherlands & 38 & 61 & 50 & 49.7 \\
\hline & Ireland & 26 & 68 & 53 & 49 \\
\hline & Estonia & 18 & 70 & 58 & 48.7 \\
\hline & Slovenia & 32 & 64 & 49 & 48.3 \\
\hline & Lithuania & 24 & 65 & 52 & 47 \\
\hline & Hungary & 35 & 59 & 43 & 45.7 \\
\hline & France & 38 & 61 & 32 & 43.7 \\
\hline & Spain & 18 & 68 & 44 & 43.3 \\
\hline & Portugal & 16 & 62 & 45 & 41 \\
\hline \multirow{8}{*}{ 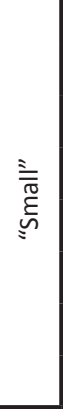 } & Romania & 23 & 53 & 43 & 39.7 \\
\hline & Latvia & 17 & 56 & 45 & 39.3 \\
\hline & Czech Republic & 16 & 54 & 43 & 37.7 \\
\hline & Bulgaria & 22 & 48 & 41 & 37 \\
\hline & Cyprus & 9 & 45 & 55 & 36.3 \\
\hline & United Kingdom & 19 & 48 & 40 & 35.7 \\
\hline & Italy & 17 & 52 & 34 & 34.3 \\
\hline & Greece & 11 & 44 & 39 & 31.3 \\
\hline $\mathrm{n} / \mathrm{a}$ & Croatia & 48 & $\mathrm{n} / \mathrm{a}$ & $\mathrm{n} / \mathrm{a}$ & $\mathrm{n} / \mathrm{a}$ \\
\hline
\end{tabular}

Source: Standard Eurobarometer 79 (spring 2013)

In some cases, the discrepancies between state size in terms of population and perceptual size are considerable. Luxembourg is a very obvious case in point. Although the Grand Duchy is the second smallest member state in terms of population size, its citizens overwhelmingly feel that they are citizens of the union $(88 \%)$, in addition to 
feeling knowledgeable about their rights as EU citizens (67\%) and confident that their voice counts in the EU (46\%). In addition, Luxembourgers have often held key positions within the EU's institutions, not merely in the early days of European integration when the community was still limited to six members. Jean-Claude Juncker's recent tenure as President of the Euro Group as well as the Commission Presidencies of Gaston Thorn in the early 1980s and Jacques Santer in the late 1990s are some of the clearest examples.

The literature on Europeanization goes some way in analyzing the extent to which participation in European integration is shaping not simply the way policies are made in the nation state, but also - and maybe more importantly - the identity of the nation state (and consequently its preferences) in relation to European integration. This argument has for instance been made about the three Benelux countries, whose participation in European integration was initially based on self-interest, but which has since then "developed into a facet of national identity" and thereby also transformed conceptions of self-interest (Jones 2005: 165).

Table 3 summarizes the grouping of member states into three different categories of perceptual size, based on their citizens' self-perceptions with regard to the three Eurobarometer questions used here.

Table 3. Categories of perceptual size

\begin{tabular}{|l|c|c|l|}
\hline Category & Average percentage & Number of states & States included \\
\hline "Large" & $50 \%$ or more & 10 & LUX, DK, MAL, FIN, GER, BEL, POL, SWE, SLK, AUT ${ }^{18}$ \\
\hline "Medium" & $40-49.9 \%$ & 9 & NL, IRE, EST, SLN, LIT, HUN, FRA, ESP, POR \\
\hline "Small" & $40 \%$ or less & 8 & ROM, LAT, CZE, BUL, CYP, UK, ITA, GRE \\
\hline
\end{tabular}

\subsection{Presentation of Findings}

This analysis distinguishes between three categories of organizational involvement in the citizens' committees of the respective initiatives. As was already pointed out, all initiatives are formally organized by transnational citizens' committees composed of seven individuals residing in seven different member states. However, they vary considerably in terms of the level of involvement of individual members in the day-to-day organization of the initiatives. Some have professional campaign workers responsible for most of the day-to-day work (e.g. Right2Water) and thus use the members of their citizens' committees mainly as figureheads for the campaign. Others emphasize that their citizens' committees are made up of many more individuals than the seven formally registered on the website of the European Commission (e.g. Fraternité 2020). Broadly speaking, however, most initiatives have only a limited number of individuals in charge of most of the campaign work. Consequently, any analysis of who organizes citizens' initiatives in practice has to take into account that an initiative's main "representative" usually does most of the work, followed by the officially registered "substitute", followed by the remaining five members of the respective "citizens' committees" (CCs). The present 


\section{STJÓRNSÝSLA}

analysis takes this into account by assigning a different number of points to different organizational roles in the respective citizens' committees, namely three points to the representative, two to the substitute, and one to each of the five remaining members of the citizens' committee.

\subsubsection{Does population size matter - and how?}

The first finding of the study is that the main organizers of the current initiatives come from a fairly limited number of countries: the sixteen initiatives' official representatives come from only six different member states, and $87 \%$ come from France, the UK, Germany and Italy, i.e. the union's four biggest states in terms of population size. The ECI appears to be particularly popular (or well-known) in France: the country accounts for no less than half of the main representatives of all initiatives. In this context, it is also worth noting that two of the initiatives - the European Initiative for Media Pluralism (EIMP) as well as Let Me Vote! - are in a sense even more French-organized than a look at their respective citizens' committees will reveal. Let me vote! is the idea of the French journalist and chairman of Euronews Philippe Cayla, and the initiative is largely run by an organization founded specifically for this purpose, namely the Paris-based Européens sans frontières/Europeans without borders. The EIMP is broadly supported by the International Alliance of Journalists, but was initiated by European Alternatives, an organization that views is itself as transnational, but is nonetheless based in the French capital. France is furthermore well-represented among the remaining members of the different initiatives' citizens' committees. With a total of 29 points, France thus has a clear first place, followed by the UK (19), Germany (18) and Italy (17).

Table 4. Most frequent origins of $\mathrm{ECl}$ organizers

\begin{tabular}{|c|l|c|c|c|c|c|}
\hline Rank & Member state & Reps & Subs & Other CC members & Total points & Population size \\
\hline 1 & France & 8 & 0 & 5 & 29 & 1 \\
\hline 2 & United Kingdom & 3 & 1 & 8 & 19 & 1 \\
\hline 3 & Germany & 2 & 3 & 6 & 18 & 1 \\
\hline 4 & Italy & 1 & 3 & 8 & 17 & 1 \\
\hline 5 & Austria & 1 & 0 & 8 & 11 & 4 \\
\hline 6 & Belgium & 0 & 4 & 2 & 10 & 3 \\
\hline 7 & Spain & 0 & 1 & 7 & 9 & 2 \\
\hline 8 & Poland & 1 & 1 & 3 & 8 & 2 \\
\hline 9 & Netherlands & 0 & 1 & 4 & 6 & 3 \\
\hline 10 & Slovenia & 0 & 1 & 2 & 4 & 5 \\
\hline & Hungary & 0 & 0 & 4 & 4 & 3 \\
\hline & Sweden & 0 & 0 & 4 & 4 & 4 \\
\hline & Luxembourg & 0 & 0 & 4 & 4 & 5 \\
\hline
\end{tabular}


The dominance of the union's larger states in the organization of ECIs is further underlined by a look at the aggregated numbers for the five categories of population size introduced above. No main representative and only one substitute comes from one of the union's six smallest states. In addition, small states also have the fewest other members of citizens' committees of all five categories, and of course also the smallest number of points overall (see table 5).

Table 5. Organizers of ECls, sorted by categories of population size

\begin{tabular}{|l|c|c|c|c|c|c|}
\hline Population size & \# of states & Reps & Subs & Other CC members & Sum & Weighted* \\
\hline Small states & 6 & 0 & 1 & 8 & 9 & 10 \\
\hline Medium-small states & 9 & 1 & 1 & 19 & 21 & 24 \\
\hline Medium states & 7 & 0 & 5 & 16 & 21 & 26 \\
\hline Medium-large states & 2 & 1 & 2 & 10 & 13 & 17 \\
\hline Large states & 4 & 14 & 7 & 27 & 48 & 83 \\
\hline
\end{tabular}

*Number of representatives multiplied by 3 , number of substitutes multiplied by 2

At the same time, this way of presenting the data only gives us a highly incomplete image of the situation. Clearly, a larger number of citizens' initiatives have to be expected to originate in the union's larger and largest states, simply because those states have so many more citizens. But if population size is taken into account - which is done here by multiplying the number of points (simple and weighted) that a member state has received by the number associated with its category of population size (1 for the largest, 5 for the smallest states ${ }^{19}$, a very different image emerges. As table 6 shows, it is now evident that the citizens of at least some of the union's smaller states are in fact highly active in making use of the ECI. Despite being a medium-small state, Austria is now head and shoulders above the rest, followed by Belgium, i.e. a medium-sized state. While still in the top group, France is now nowhere near as dominant as in the initial analysis, and is followed by two of the union's smallest states, namely Luxembourg and Slovenia. Germany, the union's largest state, has now even dropped to seventh place, tied with the Netherlands and Spain. 


\section{STJÓRNSÝSLA}

Table 6. Most frequent origins of $\mathrm{ECl}$ organizers, adjusted for population size

\begin{tabular}{|c|c|c|c|c|c|c|c|}
\hline Rank & Member state & Reps & Subs & Other CC members & Total points & $\begin{array}{l}\text { Points multiplied } \\
\text { by popul. size }\end{array}$ & Population size \\
\hline 1 & Austria & 1 & 0 & 8 & 11 & 44 & 4 \\
\hline 2 & Belgium & 0 & 4 & 2 & 10 & 30 & 3 \\
\hline 3 & France & 8 & 0 & 5 & 29 & 29 & 1 \\
\hline \multirow[t]{2}{*}{4} & Slovenia & 0 & 1 & 2 & 4 & 20 & 5 \\
\hline & Luxembourg & 0 & 0 & 4 & 4 & 20 & 5 \\
\hline 6 & United Kingdom & 3 & 1 & 8 & 19 & 19 & 1 \\
\hline \multirow[t]{3}{*}{7} & Germany & 2 & 3 & 6 & 18 & 18 & 1 \\
\hline & Netherlands & 0 & 1 & 4 & 6 & 18 & 3 \\
\hline & Spain & 0 & 1 & 7 & 9 & 18 & 2 \\
\hline 10 & Italy & 1 & 3 & 8 & 17 & 17 & 1 \\
\hline \multirow[t]{2}{*}{11} & Sweden & 0 & 0 & 4 & 4 & 16 & 4 \\
\hline & Poland & 1 & 1 & 3 & 8 & 16 & 2 \\
\hline
\end{tabular}

A look at the aggregated numbers for the five categories of population size lends support to the observation that larger states are overrepresented in the organization of European citizens' initiatives. Here, we have grouped states according to the five population size categories identified above, and then taken the average number of weighted points reached by states within each category. ${ }^{20}$ The analysis shows that a state's average number of points increases with population size: partly due to the dominant role of France (as discussed above), the biggest average numbers of points are reached by large states (20.8) and medium-large states (17).

Table 7. Organizers of ECls, sorted by categories of population size and adjusted for population size

\begin{tabular}{|l|c|c|c|c|c|c|c|}
\hline Population size & $\begin{array}{c}\text { \# of } \\
\text { states }\end{array}$ & Reps & Subs & $\begin{array}{c}\text { Other CC } \\
\text { members }\end{array}$ & $\begin{array}{c}\text { Total } \\
\text { points }\end{array}$ & $\begin{array}{c}\text { Points multiplied } \\
\text { by popul. Size }\end{array}$ & $\begin{array}{c}\text { Points divided } \\
\text { by \# of states }\end{array}$ \\
\hline Small states & 6 & 0 & 1 & 8 & 10 & 50 & 8.3 \\
\hline Medium-small states & 9 & 1 & 1 & 19 & 24 & 96 & 10.7 \\
\hline Medium states & 7 & 0 & 5 & 16 & 26 & 78 & 11.1 \\
\hline Medium-large states & 2 & 1 & 2 & 10 & 17 & 34 & 17 \\
\hline Large states & 4 & 14 & 7 & 27 & 83 & 83 & 20.8 \\
\hline
\end{tabular}

\subsubsection{Does perceptual size matter - and how?}

This leaves us with the question of how perceptual size plays out in the organization of European citizens' initiatives: are states whose citizens regard themselves as EU citizens, knowledgeable about their EU citizenship rights and confident that their voice matters 
in the EU, also more strongly represented among the organizers of the sixteen initiatives analyzed here?

Table 8 shows the most frequent origins of ECI organizers before taking population size into account. France's prominent position might be somewhat puzzling, considering that a clear majority of French citizens neither feel that their voice counts in the EU nor that they know enough about their rights as EU citizens. Nonetheless, as we have seen above, half of the main representatives of all initiatives are French. However, it could be noted that the French score for "my voice counts" is the highest in the group of states ranked as perceptually medium-sized (38\%), on par with the Netherlands and, tellingly, higher even than five of the ten states in the group of perceptually large states.

Citizens from eight of the ten countries ranked here as perceptually "large" are involved in the citizens' committees of the analyzed initiatives. The only exceptions are Malta and Finland. In the case of Malta, this might be ascribed to Malta being the smallest member state of the EU-28 in terms of population size, in addition to which there are still only rather few initiatives to begin with. Finland, on the other hand, is in some ways represented, as one of the organizers of the $30 \mathrm{~km} / \mathrm{h}$ initiative is a Finnish national residing in Brussels. Three countries ranked as perceptually "small" have no ECI organizers at all, namely the Czech Republic, Latvia and Cyprus. The latter two are of course simultaneously among the union's smallest states in terms of population size, but this also rhymes with the limited faith that their citizens have that their voice counts in the EU. This is particularly dramatic in the case of Cyprus. Despite reasonably high scores in terms of "feeling like citizens of the EU" and "knowledge of rights as EU citizens", Cypriots have by far the lowest confidence that their voice matters in the EU (only 9\%).

Table 8. Most frequent origins of $\mathrm{ECl}$ organizers

\begin{tabular}{|c|l|c|c|c|c|c|}
\hline Rank & Member state & Reps & Subs & Other CC members & Total points & Perceptual size \\
\hline 1 & France & 8 & 0 & 5 & 29 & 2 \\
\hline 2 & United Kingdom & 3 & 1 & 8 & 19 & 3 \\
\hline 3 & Germany & 2 & 3 & 6 & 18 & 1 \\
\hline 4 & Italy & 1 & 3 & 8 & 17 & 3 \\
\hline 5 & Austria & 1 & 0 & 8 & 11 & 1 \\
\hline 6 & Belgium & 0 & 4 & 2 & 10 & 1 \\
\hline 7 & Spain & 0 & 1 & 7 & 9 & 2 \\
\hline 8 & Poland & 1 & 1 & 3 & 8 & 1 \\
\hline 9 & Netherlands & 0 & 1 & 4 & 6 & 2 \\
\hline 10 & Slovenia & 0 & 1 & 2 & 4 & 2 \\
\hline & Hungary & 0 & 0 & 4 & 4 & 2 \\
\hline & Sweden & 0 & 0 & 4 & 4 & 1 \\
\hline & Luxembourg & 0 & 0 & 4 & 4 & 1 \\
\hline
\end{tabular}




\section{STJÓRNSÝSLA}

The United Kingdom and Italy stand out as countries with low average scores, but whose citizens are nonetheless quite active as ECI organizers: both are large states in population size, but "small" in terms of their citizens' self-perceptions in relation to European integration. Despite the latter, both are among the top 4 of our table. This is however before taking population size into account.

Matters look quite differently when population size is taken into account. Table 9 displays the most frequent origins of ECI organizers after multiplying the number of points achieved by each state by the number associated with its population size. As seen in the discussion on population size above, four relatively small states (in terms of population size) are now among the top 5, namely Austria, Belgium, Luxembourg and Slovenia. The first three of these are furthermore in the top category in terms of perceptual size $\left(10^{\text {th }}, 6^{\text {th }}\right.$ and $1^{\text {st }}$ place in the EU-28, respectively). Slovenia is close to the top in the medium category and still in the top half of the EU-28 (14 ${ }^{\text {th }}$ place). With the notable exceptions of the UK and Italy, six of the eight perceptually small states are in the lower half of the most frequent origins of ECI organizers.

Table 9. Most frequent origins of ECl organizers, adjusted for population size

\begin{tabular}{|c|c|c|c|c|c|c|c|}
\hline Rank & Member state & Main reps & Subs & $\begin{array}{l}\text { Other CC } \\
\text { members }\end{array}$ & Points & $\begin{array}{l}\text { Points multiplied } \\
\text { by popul. size }\end{array}$ & $\begin{array}{l}\text { Perceptual size } \\
\text { category }\end{array}$ \\
\hline 1 & Austria & 1 & 0 & 8 & 11 & 44 & 1 \\
\hline 2 & Belgium & 0 & 4 & 2 & 10 & 30 & 1 \\
\hline 3 & France & 8 & 0 & 5 & 29 & 29 & 2 \\
\hline \multirow[t]{2}{*}{4} & Luxembourg & 0 & 0 & 4 & 4 & 20 & 1 \\
\hline & Slovenia & 0 & 1 & 2 & 4 & 20 & 2 \\
\hline 6 & United Kingdom & 3 & 1 & 8 & 19 & 19 & 3 \\
\hline \multirow[t]{3}{*}{7} & Germany & 2 & 3 & 6 & 18 & 18 & 1 \\
\hline & Spain & 0 & 1 & 7 & 9 & 18 & 2 \\
\hline & Netherlands & 0 & 1 & 4 & 6 & 18 & 2 \\
\hline 10 & Italy & 1 & 3 & 8 & 17 & 17 & 3 \\
\hline \multirow[t]{2}{*}{11} & Poland & 1 & 1 & 3 & 8 & 16 & 1 \\
\hline & Sweden & 0 & 0 & 4 & 4 & 16 & 1 \\
\hline \multirow[t]{2}{*}{13} & Hungary & 0 & 0 & 4 & 4 & 12 & 2 \\
\hline & Lithuania & 0 & 1 & 1 & 3 & 12 & 2 \\
\hline 15 & Estonia & 0 & 0 & 2 & 2 & 10 & 2 \\
\hline
\end{tabular}

Table 10 shows the aggregated figures for ECI organizers grouped by categories of perceptual size. Here, the average numbers of points are fairly similar for perceptually large and medium-sized states. With population size taken into account, perceptually large state have an average of 16 points each, compared to 13.6 for the medium-sized states. 
Despite the exceptional cases of Italy and the UK, the number for the perceptually small states is considerably lower at an average of 7.4. In the small-states context in which this article is presented, it is certainly relevant to note the considerable number of small(er) state (in terms of population size) that are represented in the category of perceptually large states. This category only includes one of the union's large states (i.e. Germany), but two of the four small and five of the union's nine medium-small states. This is in fairly sharp contrast to the composition of the group of the perceptually small states. Out of the eight states in that group, five are either large or medium, which in part accounts for the higher aggregate number of weighted points achieved by the perceptually large member states. This strong representation of small states in terms of population not only within the group that considers itself to have strong perceptual power, but more importantly in the organization of the initiatives analyzed here, is certainly an important finding to be emphasized.

Table 10. Organizers of ECls, sorted by categories of perceptual size

\begin{tabular}{|l|c|c|c|c|c|c|}
\hline Perceptual size & \# of states & Reps & Subs & $\begin{array}{c}\text { Other CC } \\
\text { members }\end{array}$ & $\begin{array}{c}\text { Total points } \\
\text { (weighted) }\end{array}$ & $\begin{array}{c}\text { Points divided by } \\
\text { \# of states }\end{array}$ \\
\hline Large & 10 & 4 & 8 & 31 & 160 & 16 \\
\hline Medium & 9 & 8 & 4 & 26 & 122 & 13.6 \\
\hline Small & 8 & 4 & 4 & 0 & 59 & 7.4 \\
\hline
\end{tabular}

This leaves us with the question as to whether or not any cleavages between different groups of member states are discernible on the basis of the empirical material available at this point. Already the data on the self-perceptions of member state citizens gives some indication that there is a relevant cleavage that could be framed in terms of a North-South divide. Strikingly, the countries that were (most) negatively affected by the Eurozone debt crisis - in particular Greece and Cyprus, but also Italy - have very little faith in their role in European integration. Apart from the Greek and Italian cases, this could however - at least to some extent - also be framed as a gap between the countries of the old EU-15 and the former communist countries of the "Eastern" round of enlargement. Most of the thirteen states that acceded to the union between 2004 and 2013 have strikingly low values as regards their citizens' self-perceptions in relation to European integration. This is also reflected in a severe underrepresentation of the citizens of most of these states in the organization of European citizens' initiatives. For instance, the average original member of the European Coal and Steel Community (ECSC) receives 14 weighted points, compared to a meager 2.2 points for the average fifth/sixth enlargement country. There are some notable exceptions, however. Slovenia stands out as one of the smallest states in the union (with the minimum of 6 MEPs prescribed by the Lisbon Treaty) and as one of the recently acceded post-Communist states. Nonetheless, its citizens are active in the organization of European citizens' initiatives. 


\section{STJÓRNSÝSLA}

By contrast, many of the Northern European countries - including Sweden and Denmark - tend to identify as EU citizens, feel confident about their knowledge of their EU citizenship rights and also find that their voice counts in European integration. This is at least to some extent reflected in the composition of the sixteen analyzed initiatives' citizens' committees. The good news for small states is that states that are small in terms of population size can indeed play a very important role in the organization of citizens' initiatives. Overall, the findings suggest that perceptual size in terms of the indicators used here certainly has a role to play in whether or not citizens take it upon themselves to attempt to influence the EU's agenda-setting process by launching an initiative.

\section{Conclusions}

The empirical material that is currently available to study the role and impact of citizens from the EU's smaller and smallest states is in a way still too limited to allow for any generalizing conclusions. In this sense, the findings of the empirical analysis discussed in this paper have to be taken with a bit of caution. Nevertheless, the present analysis was able to point to a number of findings that should be relevant to investigate also in future studies. The overarching ambition in this article has been to analyze how the ECI will affect - and possibly strengthen - the role of citizens from the union's smaller and smallest states in the legislative process of the EU. As was emphasized in the theoretical discussion, the ECI's innovative and transformative potential resides not exclusively in its contribution to the strengthening of participatory democracy in the EU as such, but as much in its potential contribution to the development of transnational democracy along the lines presented in James Bohman's transformationalist democratic theory. The institutional design of the ECI promotes not only transnational civil society networking, but moreover fosters the activation of transnational EU citizenship and the emergence of transnational discursive spheres. Ideally, this can be expected also to foster the gradual development of transnational deliberation on issues dealt with in the EU's legislative institutions. From the perspective of a transformationalist democratic theory, the most remarkable aspect of the ECI is however that it fosters a democratization of the EU without emphasizing the prior need for a European demos, which sets Bohman's transformationalism apart from the (alleged) gradualism inherent in e.g. Habermas's account of postnational democracy. This is clearly a point that should strike a chord with discussions on the impact of European integration on the member states, particularly the smaller and smallest ones. The ECI provides institutional incentives as well as opportunities for EU citizens not only to initiate deliberation on perceived injustices, but also to initiate transnational communicative processes that can channel communicative power from the public sphere into the institutions of the EU political system. In these regards, the ECI has a very clear small-states angle, as the normative ideal of non-domination refers crucially to the avoidance of a hierarchy of authority that can arise from attempts at creating a European demos.

Against this backdrop of discussions in transformationalist democratic theory, it 


\section{STJÓRNMÁL \& \\ STJÓRNSÝSLA}

becomes empirically relevant to study the role that small-states citizens actually play in the organization of European citizens' initiatives. Here, this was done by analyzing the roles which citizens from different categories of member states - defined by population size and perceptual size - play in the respective organizing "citizens' committees" of the different initiatives. The main question to be answered was whether the ECI is used by citizens from the union's small states (so far) or whether it is primarily used by citizens from larger states. This analysis rested on two different conceptualizations of state size. In addition to the traditional understanding that large states are those with sizable populations, the aim in this article was to also look at the notion of perceptual size, i.e. how states - and in this case their citizens - perceive themselves as actors in international politics and, in our case, in European integration. While the empirical analysis showed that the union's largest states in terms of population size are also the ones that are most strongly represented in the organization of citizens' initiatives, a very different image emerged when population size was taken into account. Then, even a number of the union's smaller states tended to play a rather active role in the organization of initiative. This finding appears even more intriguing when put into the context of perceptual size: here, the analysis showed that citizens of states that are small in terms of population size can play an important role in using the ECI as a tool to participate in the EU legislative process. In order to do so, they however need to be knowledgeable about their rights as EU citizens and to some extent also have confidence that their voice actually matters in the EU. To some limited extent, this finding even puts the existing cleavage between the countries of the EU-15 and the former communist countries of the "Eastern" round of Enlargement into perspective: the citizens of states such as Poland, Slovakia, Estonia and Slovenia strongly view themselves as citizens of the union who are aware of their rights of EU citizens and are consequently also well-represented among the organizers of the first round of initiatives analyzed here.

To bring the discussion back to the union's small(er) states: the good news, as argued above, is that the ECI is in fact a tool that is already now used quite extensively by citizens from smaller states. Luxembourg is arguably the most relevant case in point: the country is among the union's smallest in terms of population size, but at the same time the EU leader as regards its citizens' self-perception as EU citizens capable of influencing the EU's legislative process. Tellingly, the country is therefore also represented in a quarter of the analyzed initiatives.

Future studies on the basis of a larger number of initiatives will have to address whether this pattern can be confirmed, most importantly in relation to newer and smaller member states such as Malta, which have considerable perceptual size, but are not represented among any of the initiatives so far. In addition, normative issues regarding emerging cleavages between groups of member states have to be addressed and explored. If the ECI is to have an impact on the EU's ongoing democratization depends not only on whether the union's citizens make use of it at all, but whether it is used with similar frequency across all member states. 


\section{STJÓRNSÝSLA}

\section{Notes}

1. The term European Citizens' Initiative is somewhat misleading, since the ECI borrows the term citizens' initiative from a direct democratic design that would imply a subsequent binding popular vote (Smith 2012: 281). And although the ECI is sometimes (mistakenly) portrayed as an element of direct democracy (e.g. Kaufmann 2012: 228) - or at least as a first step in this direction - the most appropriate way to describe the ECI is as an agenda initiative, examples of which exist e.g. in Austria (Giese 2012), Spain (Cuesta-López 2012) or Poland (Rytel-Warzocha 2012).

2 The details of the process of registration, signature collection and verification, and on the process after the successful signature-collection process is described e.g. in Kaufmann (2012) or Smith (2012).

3 The first eight initiatives, officially registered on the website of the European Commission between May 9 and August 27, 2012, finished their signature collection on November 1, 2013. Their respective one-year signature-collection periods were extended as a consequence of technical difficulties that the Commission experienced with its own online signature-collection software (OCS) in the first few months of the ECI. A complete overview of all initiatives, including their registration dates and signature-collection deadlines, is available on the European Commission's ECI website at http://ec.europa.eu/citizens-initiative/public/initiatives/ongoing.

4 More information on these initiatives is available via their respective websites, i.e. http://www. stopvivisection.eu, http://www.oneofus.eu, and http://www.right2water.eu.

5 It should be added that in addition to the required one million signatures, initiatives also have to reach a minimum number of signatures in at least one quarter of the 28 member states. This minimum number is determined by multiplying a state's number of Members of the European Parliament (MEPs) by 750 and is thus somewhat higher in smaller states than in larger ones.

6 Jóhanna Jónsdóttir (2012), for instance, applies a Europeanization perspective in her analysis of the channels for influence that the European Economic Area (EEA) Agreement provides for nonmembers such as Iceland and looks both at non-members ability to "upload" their policy preferences in the agenda-setting phase and their chances to avoid "downloading" unfavorable policy choices made at the European level. By contrast, Matilda Broman (2008) looks at institutional opportunities such as the Council Presidency that small(er) member states such as Sweden can use to promote issues that are of particular relevance for them.

7 As a matter of fact, the original ambition of movements such as the German MebrDemokratie e.V. at the time of the Convention on the Future of Europe was to introduce elements of direct democracy into the decision-making processes of the EU, which obviously need to be distinguished from elements of participatory democracy.

8 A key example of this is that EU citizenship allows member state nationals not only to vote, but also to run for office in local/municipal as well as European Parliament elections in their member state of residence, even if they are not citizens of that state.

9 In Bohman's account, this is also the core problem of any "transformationalist" democratic theory that does not move beyond the normative ideal of popular sovereignty (cf. Conrad 2011).

10 The analysis also includes the European Initiative for Media Pluralism, which was initially registered within the time frame of this study, but later withdrawn and reregistered in August 2013.

11 The full text of the consolidated Treaty on European Union can be found at http:/ / eur-lex.europa. $\mathrm{eu} / \mathrm{en} / \mathrm{treaties} / \mathrm{dat} / 11992 \mathrm{M} / \mathrm{htm} / 11992 \mathrm{M} \cdot \mathrm{html}$.

12 The Lisbon Treaty has been in force since December 2009 and includes many of the institutional reforms that had already been included in the Treaty Establishing a Constitution for Europe, including the provision for the introduction of a European Citizens' Initiative. However, the Constitutional Treaty was voted down in two referenda in France and the Netherlands in the spring of 2005, necessitating a (partial) renegotiation that took place in the spring of 2007 and that most importantly stripped the treaty of its constitutional symbolism (e.g. Conrad 2009: chap. 8). The text of the Lisbon Treaty can be found at http://eur-lex.europa.eu/JOHtml.do?uri=OJ:C:2007:306:SOM:EN:HTML. 


\section{STJÓRNMÁL \& STJÓRNSÝSLA}

13 The upcoming EP elections in 2014 will be of interest in this regard, as the Lisbon Treaty states that the Commission President has to be chosen taking into account the result of the EP elections.

14 A high-profile example that is sometimes mentioned in this context is Daniel Cohn-Bendit, who has represented the German and well as the French Greens in the European Parliament (Burns 2013: 168).

15 This minimum number of threshold varies between states, as it is connected to the number of seats that each state holds in the European Parliament. The minimum number of signatures is determined by multiplying a state's number of MEPs by 750 . Since the number of MEPs that each state has follows the principle of digressive proportionality (through which smaller states are overrepresented), it follows that the minimum number of signatures in the union's smaller states is somewhat bigher in relation to the overall population than in larger states.

16 Some of them certainly address issues that are more relevant or topical in some countries than in others, but nonetheless express concerns that at least in principle should be relevant in all of the EU's member states. The European Initiative for Media Pluralism (EIMP) is a case in point, driven as it is by individuals coming from states in which media pluralism has been under threat, such as most importantly Hungary and Italy. Nonetheless, the campaign advances goals that the union as a whole should have an interest in promoting.

17 Regulation EU No. (211/2011).

18 As the most recently acceded state, Croatia is not listed in this table because data are only available for the question of "my voice counts in the EU". In this category, the country does however have the second highest score of the entire EU-28 (48\%), second only to Denmark (56\%).

19 For example, Estonia (as one of the union's six smallest states) would have its two points multiplied by five, whereas France or Germany (as two of the biggest states) would not see any changes to their respective 29 or 18 points (multiplied by one).

20 For example, the six smallest states in the union reach a total of ten points, which is then multiplied by five to take account of state size. This number (50) is then divided by the number of states in this category (6), which means that the average small state in the EU reaches 8.3 points.

\section{References}

Bache, I., George, S., Bulmer, S. (2011). Politics in the European Union (3"d ed.). Oxford/New York: Oxford University Press.

Bohman, J. (2005). "From Demos to Demoi: Democracy across Borders", Ratio Juris 18(3): 293-314.

Bohman, J. (2007a). "Democratizing the Transnational Polity", RECON Online Working Paper 2007/02 (available at www.reconproject.eu/projectweb/portalproject/RECONonlineWorkingPapers.html).

Bohman, J. (2007b). Democracy across Borders. From Dêmos to Dêmoi. Cambridge, MA: MIT Press.

Broman, M. (2008). Taking Advantage of Institutional Possibilities and Network Opportunities. Analyzing Swedish Strategic Action in EU Negotiations. Lund Political Studies 152. Lund: Department of Political Science.

Bouza García, L. (2012). "How Could the New Article 11 TEU Contribute to Reduce the EU's Democratic Malaise?”, in Dougan, M., Shuibhne, N., Spaventa, E. (eds.), Empowerment and Disempowerment of the European Citizen. Portland, OR: Hart Publishing.

Bouza, L. and Greenwood, J. (2013). “The European Citizens' Initiative and Civil Society: Evidence from One Year of Implementation", paper presented at the ECPR General Conference in Bordeaux, September 2013.

Burns, C. (2013). “The European Parliament”, in Cini, M. \& Pérez-Solórzano Borragán, N. (eds.), European Union Politics ( $4^{\text {th }}$ ed.). Oxford: Oxford University Press.

Conrad, M. (2011). “The European Citizens' Initiative: Transnational Democracy in the EU at last?", Stjórnmál og stjórnsýsla 7(1): 5-22. 


\section{STJÓRNSÝSLA}

Conrad, M. (2012). „Gæti tilkoma Borgarafrumkvæðis Evrópu eflt hlutverk smáríkja innan ESB?““. Evrópuvefurinn 22.12.2011. http://evropuvefur.is/?id=61439. (Last accessed: 15.10.2013).

Conrad, M. (2013). "Bridging the Gap? European Citizens' Initiatives as the Missing Link between 'the EU' and its Citizens", paper presented at the ECPR General Conference in Bordeaux, September 2013.

Conrad, M. \& Steingrímsdóttir, F. (2012). "F-Word of Blueprint for Institutional Reform: European Integration and the Continued Relevance of Federalism", Stjórnmál og stjórnsýsla 8(2): 245-264.

Cuesta-López, V. (2012). "The Spanish Agenda Initiative and the Reform of its Legal Regime: A New Chance for Participatory Democracy?”, in Setälä, M. \& Schiller, T. (eds.), Citizens' Initiatives in Europe. Procedures and Consequences of Agenda-Setting by Citizens. Houndsmills: Palgrave Macmillan.

Etzioni, A. (2007). “The Community Deficit”, Journal of Common Market Studies 45(1): 23-42.

Giese, K. (2012). "The Austrian Agenda Initiative: An Instrument Dominated by Opposition Parties", in Setälä, M. \& Schiller, T. (eds.), Citizens' Initiatives in Europe. Procedures and Consequences of AgendaSetting by Citizens. Houndsmills: Palgrave Macmillan.

Habermas, J. (1992). Faktizität und Geltung. Frankfurt am Main: Suhrkamp.

Jones, Erik (2005). "The Benelux Countries: Identity and Self-Interest", in Bulmer, Simon \& Lequesne, Christian (eds.), The Member States of the European Union. Oxford/New York: Oxford University Press.

Jónsdóttir, J. (2013). Europeanization and the European Economic Area: Iceland's Participation in the EU's policy process. Abingdon: Routledge.

Kaufmann, B. (2012). “Transnational 'Babystep': The European Citizens' Initiative”, in Setälä, M. \& Schiller, T. (eds.), Citizens' Initiatives in Europe. Procedures and Consequences of Agenda-Setting by Citizens. Houndsmills: Palgrave Macmillan.

Knaut, A. \& Keller, R. (2012) „Die Entstehung transnationaler Diskursräume durch die Europäische Bürgerinitiative“, Forscbungsjournal Soziale Bewegungen 2012(4): 37-47.

Maurer, A. \& Vogel, S. (2009). „Die Europäische Brgerinitiative. Chancen, Grenzen und Umsetzungsempfehlungen“, SWP-Studie 28, Stiftung Wissenschaft und Politik Berlin.

Moravcsik, A. (2008). "The Myth of Europe's Democratic Deficit", Intereconomics: Journal of European Public Policy (2008): 331-340.

Leinen, J. (2012). „Die Europäische Bürgerinitiative - Ein wichtiger Schritt in Richtung europäische Öffentlichkeit", Forschungsjournal Soziale Bewegungen 2012(4): 28-32.

Quittkat, C. (2012). „Die EBI - (K)ein Tor zur europäischen Politik für ,Normalbürger““, Forscbungsjournal Soziale Bewegungen 2012(4): 69-79.

Rytel-Warzocha, A. (2012). "Popular Initiatives in Poland: Citizens' Empowerment or Keeping Up Appearances”, in Setälä, M. \& Schiller, T. (eds.), Citizens' Initiatives in Europe. Procedures and Consequences of Agenda-Setting by Citizens. Houndsmills: Palgrave Macmillan.

Smismans, Stijn (2013). "Democracy and Legitimacy in the European Union", in Cini, M. \& PérezSolórzano Borragán, N. (eds.), European Union Politics ( $4^{\text {th }}$ ed.). Oxford: Oxford University Press.

Smith, G. (2012). “The European Citizens' Initiative: A New Institution for Empowering Europe's Citizens?", in Dougan, M., Shuibhne, N., Spaventa, E. (eds.), Empowerment and Disempowerment of the European Citizen. Portland, OR: Hart Publishing.

Thorhallsson, B. (2006). 'The Size of States in the European Union: Theoretical and Conceptual Perspectives', European Integration 28(1): 7-31.

Warleigh, A. (2003) Democracy in the European Union. London/Thousand Oaks: SAGE Publications.

Warleigh-Lack, A. \& Drachenberg, R. (2013). "Policy-making in the European Union”, in Cini, M. \& Pérez-Solórzano Borragán, N. (eds.), European Union Politics (4 $4^{\text {th }}$ ed.). Oxford: Oxford University Press. 